\title{
KONSEP KAMPUNG WISATA BELANJA BERKELANJUTAN KLASTER INDUSTRI KERAJINAN MUTIARA, EMAS DAN PERAK (MEP) DI KELURAHAN KARANG PULE, KECAMATAN SEKARBELA, KOTA MATARAM
}

\author{
Ima Rahmawati Sushanti, Agus Kurniawan \\ Perencanaan Wilayah dan Kota, Universitas Muhammadiyah Mataram \\ *imarahmawati77@gmail.com
}

\begin{tabular}{l} 
INFO ARTIKEL \\
\hline Riwayat Artikel: \\
Diterima: 20-1 1-2017 \\
Disetujui: 23-12-2017 \\
\hline Kata Kunci : \\
Klaster \\
Industry \\
Kampung \\
Wisata \\
Belanja
\end{tabular}

\begin{abstract}
ABSTRAK
Abstrak: Keberadaan klaster industri di Kota Mataram memberikan pengaruh sosial, ekonomi dan lingkungan terhadap kawasan permukiman sekitarnya (Sushanti, Ima R, 2015). Sesuai Rencana Tata Ruang Wilayah Kota Mataram tahun 2011 - 2031 klaster industri MEP di Kelurahan Karang Pule, Kecamatan Sekarbela ditetapkan sebagai kawasan pariwisata belanja. Tujuan penelitian adalah menentukan konsep kampung wisata belanja dalam rangka penataan klaster industri dan kawasan permukiman sekitarnya yang terpadu, secara fisik, ekonomi dan sosial berdasarkan komponen perancangan. Hasil penelitian adalah konsep kampung wisata belanja berkelanjutan yang layak, produktif dan partisipatif mengintegrasikan potensi klaster industri dan kawasan permukiman sekitarnya di Kelurahan Karang Pule, Kecamatan Sekarbela, Kota Mataram.
\end{abstract}

\begin{abstract}
The existence of industrial clusters in Mataram City gives social, economic and environmental influence to the surrounding residential areas (Sushanti, Ima $R$, 2015). According to the Mataram City Spatial Plan in 2011 - 2031 MEP industry clusters in Karang Pule Village, Sekarbela Sub-district is designated as a shopping tourism area. The objective of the research is to determine the concept of shopping village in order to arrange the cluster of industry and surrounding area of integrated settlement, physically, economically and socially based on the design component. The result of the research is the concept of a viable, productive and participatory sustainable shopping village to integrate the potential of industrial cluster and surrounding residential area in Karang Pule Village, Sekarbela Subdistrict, Mataram City.
\end{abstract}

\section{A. LATAR BELAKANG}

Kota Mataram merupakan kota yang memiliki banyak sekali potensi, salah satunya adalah potensi industri. Keberadaan klaster industri di Kota Mataram memberikan pengaruh sosial, ekonomi dan lingkungan terhadap kawasan permukiman sekitarnya [12].

Kelurahan Karang Pule merupakan salah satu kelurahan yang berada di kecamatan Sekarbela, Kota Mataram yang ditetapkan sebagai klaster industri kecil unggulan untuk kerajinan Mutiara, Emas dan Perak (MEP) di Kota Mataram sesuai Keputusan Walikota Mataram Nomor 526/X/2009 tentang Penetapan
Klaster Industri Kecil Unggulan Kota Mataram [11]. Berdasarkan Peraturan Daerah No. 12 Tahun 2011 tentang Rencana Tata Ruang Wilayah (RTRW) Kota Mataram tahun 2011 - 2031, kecamatan Sekarbela termasuk dalam pengembangan kawasan perumahan sedangkan kelurahan Karang Pule ditetapkan sebagai kawasan pariwisata belanja dan pengembangan industri kecil [12].

Menurut Undang - Undang Republik Indonesia No 3 Tahun 2014 tentang Perindustrian, industri adalah kegiatan ekonomi yang mengelola bahan mentah, bahan baku, barang setengah jadi, dan atau barang jadi menjadi barang dengan nilai yang lebih tinggi untuk penggunaanya termasuk kegiatan 
24 | JPe | Vol. 3, No. 1, Februari 2018, hal 23-29

rancangan bangun dan perekayasaan industri [15]. Menurut Undang - Undang Republik Indonesia No 10 Tahun 2009 tentang Kepariwisataan, pariwisata adalah berbagai macam kegiatan wisata dan didukung berbagai fasilitas serta layanan yang disediakan oleh masyarakat, pengusaha, pemerintah dan Pemerintah Daerah [14]. Jadi Pariwisata Belanja merupakan suatu kegiatan wisata menikmati daya tarik dari kawasan dan membeli keperluan yang khas dan menarik di lokasi tersebut.

Keberadaan klaster industri MEP memberikan implikasi pada kelayakan kawasan permukiman di sekitarnya dengan munculnya permukiman kumuh sedangkan kawasan permukiman yang berada di luar klaster industri MEP termasuk dalam kategori cukup layak dan layak. Implikasi negatif lainnya adalah munculnya kesenjangan sosial, kurang optimalnya kelembagaan, khususnya dalam pelibatan masyarakat dan atau komunitas [9].

Berdasarkan komponen-komponen pendukung kawasan wisata belanja, yaitu : 1) ketersediaan produk, 2) kelengkapan fasilitas pendukung dan 3) aksesibilitas [9]. Klaster industri MEP di kelurahan Karang Pule masih belum layak sebagai kawasan wisata belanja, khususnya pada aspek kelengkapan fasilitas pendukung dan aksesibilitas. Upaya pengembangan yang dilakukan, antara lain adalah : 1) ketersediaan produk lebih ditekankan pada peningkatan hasil produksi dan inovasi, 2) kelengkapan fasilitas dengan peningkatan fasilitas pendukung wisata belanja, pelibatan masyarakat dalam mendukung dan memelihara fasilitas yang ada serta merencanakan pembagian blok pengembangan berdasarkan fungsi kawasan dan 3) aksesibilitas lebih ditekankan pada peningkatan kualitas jalan, pengadaan pedestrian dan parkir yang memadai [16]. Bahwa terdapat tiga hal mendasar yang dicirikan oleh klaster industri, terlepas dari perbedaan struktur, ukuran ataupun sektornya [3], yaitu: 1) Komonalitas atau keserupaan atau kebersamaan atau kesatuan (Commonality), 2) Konsentrasi (Concentration) dan 3) Konektivitas (Connectivity)

Masyarakat lokal berperan penting dalam pengembangan desa wisata karena sumber daya dan keunikan tradisi dan budaya yang melekat pada komunitas tersebut merupakan unsur penggerak utama kegiatan desa wisata. Di lain pihak, komunitas lokal yang tumbuh dan hidup berdampingan dengan suatu objek wisata menjadi bagian dari sistem ekologi yang saling kait mengait. Keberhasilan pengembangan desa wisata tergantung pada tingkat penerimaan dan dukungan masyarakat lokal [10]. Kelembagaan sebagai pola perilaku yang stabil, dihargai dan berlaku dalam waktu yang lama, maka bagian pokok lainnya yang penting untuk diperhatikan dalam pembahasan mengenai kinerja kelembagaan adalah tentang pola perilaku atau pola interaksi yang terjalin antar pelaku dalam suatu kelembagaan [6].

Selain sebagai tempat tinggal, rumah saat ini juga berkembang ke arah fungsi produktif [7]. Konsep rumah dan kerja termasuk dimensi sosial dan budaya , dapat diuraikan sebagai berikut:

1. Rumah (saja): rumah yang digunakan sebagai tempat tinggal tanpa keg iatan lain yang berarti.

2. Rumah Produktif: rumah yang sebagian digunakan untuk produktif atau kegiatan ekonomi, konsekuensinya juga timbul hubungan antara aspek produksi dan perawatan rumah.

Berdasarkan Permen PU Nomor 06/PRT/M/2007 tentang Rencana Tata Bangunan dan Lingkungan [13], ada 7 (tujuh) komponen rancangan yaitu: 1) Struktur peruntukan lahan, 2) Intensitas pemanfaatan lahan, 3) Tata bangunan, 4) Sistem sirkulasi dan jalur penghubung, 5) Sistem ruang terbuka hijau, 6) Tata kualitas lingkungan, 7) Sistem sarana dan utilitas lingkungan.

Oleh karena itu diperlukan konsep penataan klaster industri dan kawasan permukiman sekitarnya yang terpadu, baik secara fisik, ekonomi dan sosial. Sehingga dapat meminimalisir dampak negatif yang terjadi dan kawsaan tersebut menjadi lebih layak dan berkembang potensinya sebagai kawasan wisata belanja.

Konsep adalah generalisasi dari sekelompok fenomena tertentu, sehingga dapat dipakai untuk menggambarkan barbagai fenomena yang sama [5]. Konsep merupakan suatu kesatuan pengertian tentang suatu hal atau persoalan yang dirumuskan. Dalam merumuskan kita harus dapat menjelaskannya sesuai dengan maksud kita memakainya.

Wisata belanja merupakan wisata yang menawarkan belanja sebagai kegiatan utama, ketika mencari kebutuhan yang diinginkan mulai dari belanja barang-barang antik, barang-barang modern hingga kebutuhan akan buah tangan ciri khas daerah kunjungan daerah wisata yang dapat dibawa ketika meninggalkan objek wisata. [2]

Pariwisata berkelanjutan adalah ketika wisatawan dapat menikmati liburan mereka dan sekaligus menghargai budaya masyarakat sekitar maupun lingkungan sekitar. Hal ini juga berarti bahwa masyarakal lokal mendapatkan keuntungan dari pengembangan pariwisata tersebut. Peran dari pariwisata berkelanjutan adalah untuk memastikan pencegahan kerusakan lingkungan dan eksploitasi budaya sebagai dampak dari pengembangan pariwisata [1]. 


\section{B. METODE PENELITIAN}

Lokasi dari penelitian ini berada di Kelurahan Karang Pule, Kecamatan Sekarbela Kota Mataram. Pendekatan yang digunakan dalam penelitian ini merupakan pendekatan rasionalistik yang bersumber dari teori dan kebenaran empirik. Jenis penelitian yang digunakan adalah deskriptif kualitatif dengan menggambarkan secara sistematis mengenai suatu keadaan, situasi, program tertentu [5]. Metode pengumpulan data yang digunakan adalah dengan pengumpulan data primer berupa observasi secara langsung wawancara dan kuesioner. Adapun penelitian ini dilakukan dengan menggunakan teknik purposive sampling.

\section{HASIL DAN PEMBAHASAN}

\section{Gambaran Umum Kawasan}

Kelurahan Karang Pule memiliki luas 106,7 $\mathrm{Km}^{2}$. Kelurahan Karang Pule memilliki 544 KK dengan jumlah penduduk 10.423 jiwa yang terbagi menjadi 7 (tujuh) lingkungan. Kelurahan Karang Pule yang terbagi menjadi 7 (tujuh) lingkungan yaitu:

a) Lingkungan Karang Pule;

b) Lingkungan Pande Besi;

c) Lingkungan Pande Mas Barat;

d) Lingkungan Pande Mas Timur;

e) Lingkungan Karang Seme;

f) Lingkungan Mas Mutiara, dan;

g) Lingkungan BTN Kekalik.

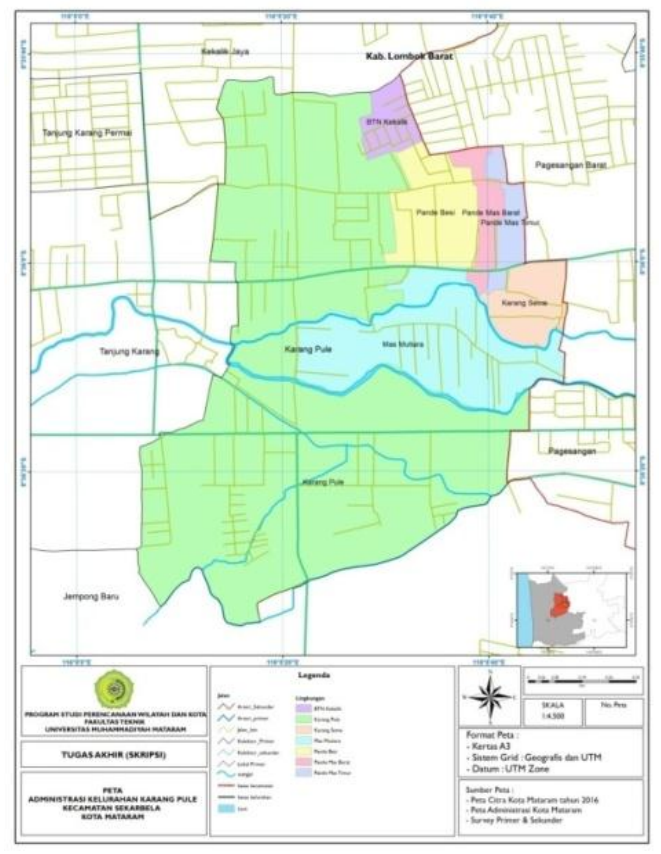

Gambar 1. Peta Kecamatan Sekarbela

\section{Komponen Perancangan}

a. Struktur Penggunaan Lahan

Struktur penggunaan lahan adalah komponen perancangan yang berperan penting dalam pengalokasian tata guna lahan yang ditetapkan ketentuan rencana tata ruang. Dalam pengalokasian peruntukan di Kelurahan Karang Pule, Kecamatan Sekarbela Kota Mataram merupakan kawasan permukiman dan kawasan pariwisata belanja

\section{b. Intensitas Pemanfaatan Lahan}

Intensitas pemanfaatan lahan adalah tingkat alokasi dan distribusi luas lantai maksimum bangunan terhadap lahan/ tapak peruntukannya. Intensitas pemanfaatan lahan perlu diatur sedemikian rupa dalam bentuk pengaturan pengelolaan area peruntukkan. Dalam hal ini kepadatan bangunan yang ada di kawasan klaster industri MEP yang ada di Keluarahan Karang Pule, Kecamatan Sekarbela, Kota Mataram sekitar 70-80 rumah/Ha yang termasuk ke dalam kawasan yang sangat padat.

c. Tata Bangunan dan Lingkungan

Tata bangunan adalah kegiatan penataan bangunan gedung beserta lingkungannya sebagai wujud pemanfaatan ruang, meliputi berbagai aspek termasuk pembentukan citra atau karakter fisik lingkungan, besaran, dan konfigurasi dari elemen-elemen: blok, kaveling atau petak lahan, bangunan, serta ketinggian pola, kepadatan, vegetasi dan elevasi lantai bangunan. Dalam hal ini keberadaan klaster industri MEP memberikan implikasi pada kelayakan kawasan permukiman di sekitarnya dengan munculnya permukiman kumuh sedangkan kawasan permukiman yang berada di luar klaster industri MEP termasuk dalam kategori cukup layak dan layak [9].

d. Sistem Sirkulasi dan Jalur Penghubung

Sistem sirkulasi dan jalur penghubung terdiri dari jaringan jalan dan pergerakan, baik pergerakan kendaraan maupun pergerakan manusia dengan berbagai aktivitas di dalamnya. Dalam hal ini pada lokasi klaster industri Mutiara, Emas dan Perak terbagi menjadi jalan kolektor primer, jalan lingkungan dan gang-gang yang ada di masing-masing lingkungan di Kelurahan Karang Pule. Kondisi jalan lingkungan 
26 | JPe| Vol. 3, No. 1, Februari 2018, hal 23-29 yang ada sebagian besar sudah menggunakan beton, namun ada beberapa jalan yang masih merupakan jalan setapak.
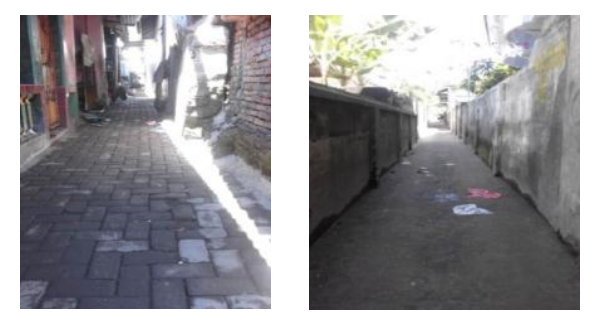

Gambar 2. Kondisi Fisik Lingkungan di Kelurahan Karang Pule

- Sistem Ruang Terbuka dan Tata Hijau

Pada lokasi klaster industri MEP, sistem ruang terbuka dan tata hijaunya sangat minim. Hal ini terjadi karena kawasan ini merupakan kawasan yang padat permukiman sehingga tidak memiliki ruang terbuka yang cukup sesuai dengan standar yang telah ditentukan.

- Tata Kualitas Lingkungan

Melihat keadaan yang ada di kawasan klaster industri MEP saat ini, kualitas lingkungannya masih belum memadai. Hal ini dapat dilihat dari kondisi rumah dan lingkungan yang kumuh atau tidak layak huni. Terdapat kawasan permukiman tidak layak atau kumuh pada 3 (tiga) lingkungan yang berada di klaster industri MEP yaitu Lingkungan Pande Besi, Pande Mas Timur dan Pande Mas Barat. Sedangkan kawasan permukiman cukup layak terdapat di Lingkungan Mas Mutiara. Dalam hal ini dibutuhkan keterlibatan masayarakat secara aktif dan dukungan lembaga atau pemerintah setempat. Namun, hal ini berbeda dengan kondisi yang ada, karena kurangnya adanya kontrol dan aturan dari pemerintah terkait yang mengatur secara khusus akan keberadaan industri kerajinan MEP [9].

- Sistem Prasarana dan Kualitas Lingkungan Sistem prasarana dan utilitas lingkungan merupakan kelengkapan dasar fisik dari suatu lingkungan yang pengadaannya dapat menjadikan lingkungan tersebut dapat beroperasi dan berfungsi sebagaimana mestinya. Berdasarkan Rencana Tata Ruang Wilayah (RTRW) Kota Mataram tahun 2011 2031 kawasan wisata belanja. klaster industri MEP di kelurahan Karang Pule masih belum layak sebagai kawasan wisata belanja, khususnya pada aspek kelengkapan fasilitas pendukung dan aksesibilitas [16].
Berdasarkan Peraturan Daerah No. 12 Tahun 2011 tentang Rencana Tata Ruang Wilayah (RTRW) Kota Mataram tahun 2011 - 2031, kecamatan Sekarbela termasuk dalam pengembangan kawasan perumahan sedangkan Kelurahan Karang Pule ditetapkan sebagai kawasan pariwisata belanja dan pengembangan industri kecil. Adanya dasar hukum tersebut dapat menjadi acuan atau panduan dalam mengembangkan dan mewujudkan industri klaster Mutiara, Emas dan Perak (MEP) yang ada di Keluarahan Karang Pule sebagai kawasan wisata belanja yang dapat menjadi daya tarik wisatawan domestik maupun mancanegara.

\section{Isu strategis}

a. Potensi

Adapun potensi keberadaan klaster industri MEP adalah sebagai berikut:

- Keberadaan industri MEP berpotensi untuk menjadikan kawasan tersebut menjadi kawasan wisata belanja;

- Keberdaan industri MEP berpotensi untuk mengurangi pengangguran dan menciptakan lapangan pekerjaan untuk masyarakat setempat;

- Keberadaan industri MEP berpotensi untuk meningkat kesejahteraan dan kemakmuran masyarakat setempat;

- Keberadaan industri MEP berpotensi untuk proses pengembangan wilayah yang lebih maju sesuai dengan visi dan misi kawasan yang ada.

b. Masalah

Adapun masalah yang ada di kawasan klaster industri MEP adalah sebagai berikut:

- Masalah kepadatan bangunan dan kelayakan bangunan yang masih minim;

- Kualitas Sumber Daya Manusia (SDM) yang masih rendah;

- Ketersedian sarana dan prasarana yang belum memadai;

- Kurangnya partisipasi dan keterlibatan masyarakat secara aktif terhadap kelembagaan;

- Kurangnya kesadaran masyarakat dalam menjaga lingkungan sekitar dan memperhatikan kondisi tempat tinggal;

- Kurang adanya kontrol dari pemerintah setempat terhadap kesenjangan sosial yang terjadi akibat keberadaan klaster industri MEP. 
c. Harapan Masyarakat

Dari hasil wawancara dapat diketahui bahwa harapan masyarakat pada aspek sosial, ekonomi dan lingkungan yang berpengaruh tersebut adalah :

- Harapan masyarakat terhadap implikasi sosial tersebut adalah dengan pendidikan non formal melalui pelatihan atau kursus yang berhubungan dengan kreatifitas dan pembuatan kerajinan MEP juga industri yang secara turun temurun sehingga dia lebih dikelola dengan baik.

- Harapan masyarakat terhadap implikasi ekonomi adalah usaha yang berkelanjutan untuk tumbuh dan membangkitkan serta menciptakan lapangan pekerjaan bagi masyarakat yang belum memiliki pekerjaan.

- Harapan masyarakat terhadap implikasi lingkungan yaitu diperlukannya pengaturan tata letak bangunan sehingga tercipta lingkungan dengan kondisi bangunan yang layak untuk ditempati, melakukan menajemen sistem sampah dan pembuangan limbah sehingga mengurangi dampak negatif terhadap kualitas perumahan masyarakat yang mengelilingi klaster industri MEP, sistem pengaturan dan pengelolaan yang baik dalam berbagai aspek untuk meminimalisir perubahan yang terjadi sebagai akibat dari klaster industri MEP ini, meningkatkan fasilitas pendukung yang lebih memadai dalam mendukung kerajinan bisnis MEP juga pengelolaan menajemen yang baik dan ramah lingkungan agar tidak menyebabkan polusi di daerah sekitarnya.

\section{Konsep Penataan Makro}

Konsep penataan makro ditentukan dengan berdasarkan 1) komponen perancangan, 2) kebijakan, dan 3) isu strategis (potensi, masalah dan harapan masyarakat) dan memperhatikan aspek pembangunan berkelanjutan, yaitu terwujudnya klaster industri MEP dan kawasan permukiman sekitarnya sebagai Kampung

\section{Wisata Belanja Berkelanjutan.}

\section{Konsep Penataan Mikro}

Kampung wisata berkelanjutan sebagai konsep makro selanjutnya diimplementasikan dalam upaya penataan secara detail pada masingmasing aspek pembangunan berkelanjutan, baik dari aspek sosial, ekonomi dan lingkungan.

a. Pada aspek sosial, klaster industri MEP dan kawasan permukiman sekitarnya dalam rangka mengurangi kesenjangan sosial yang ada, meningkatkan peran kelembagaan serta fungsi kontrol maka perlu dilakukan upaya partisipatif dari segenap masyarakat dan kelembagaan bekerjasama dengan stakeholders terkait.

b. Pada aspek ekonomi, dalam rangka menciptakan lapangan pekerjaan, meningkatkan pendapatan ekonomi bagi masyarakat pengrajin dan atau pengusaha serta masyarakat non pengrajin dan atau pengusaha serta pertumbuhan ekonomi kawasan maka dilakukan melalui upaya peningkatan produktivitas masyarakat dengan memperhatikan potensi dan karakteristik yang dimiliki masyarakat di kawasan tersebut.

c. Pada aspek lingkungan, sebagai upaya untuk mengatur tata bangunan dan lingkungan serta sarana prasarana yang memadai maka dilakukan upaya meciptakan kawasan pariwisata belanja yang layak sebagai destinasi wisata dan terintegrasi antara klaster industri MEP dan kawasan permukiman sekitarnya.

\section{SIMPULAN DAN SARAN}

Dari penelitian yang telah dilakukan, dapat disimpulkan sebagai berikut:

Konsep penataan kawasan Klaster Industri MEP di Keluarahan Karang Pule adalah sebagai kawasan pariwisata belanja yang lebih layak, produktif dan partisipatif sehingga dapat menjadi destinasi wisata belanja produk unggulan MEP yang semakin menarik bagi wisatawan dan dapat meningkatkan perekonomian masyarakat.

1. Pada aspek sosial, klaster industri MEP dan kawasan permukiman sekitarnya dalam rangka mengurangi kesenjangan sosial yang ada, meningkatkan peran kelembagaan serta fungsi kontrol maka perlu dilakukan upaya partisipatif dari segenap masyarakat dan 
28 | JPe| Vol. 3, No. 1, Februari 2018, hal 23-29

kelembagaan bekerjasama dengan stakeholders terkait.

2. Pada aspek ekonomi, dalam rangka menciptakan lapangan pekerjaan, meningkatkan pendapatan ekonomi bagi masyarakat pengrajin dan atau pengusaha serta masyarakat non pengrajin dan atau pengusaha serta pertumbuhan ekonomi kawasan maka dilakukan melalui upaya peningkatan produktivitas masyarakat dengan memperhatikan potensi dan karakteristik yang dimiliki masyarakat di kawasan tersebut.

3. Pada aspek lingkungan, sebagai upaya untuk mengatur tata bangunan dan lingkungan serta sarana prasarana yang memadai maka dilakukan upaya meciptakan kawasan pariwisata belanja yang layak sebagai destinasi wisata dan terintegrasi antara klaster industri MEP dan kawasan permukiman sekitarnya.

\section{UCAPAN TERIMAKASIH}

Penulis mengucapkan terimakasih kepada seluruh pihak yang telah membantu dan mendukung proses penyelesaian penelitian dan publikasi ilmiah ini, yaitu :

1. Program Studi Perencanaan Wilayah dan Kota, Fakultas Teknik, Universitas Muhammadiyah Mataram.

2. Tim Open Journal System Planoearth.

3. Aparat dan masyarakat Kelurahan Karang Pule, Kecamatan Sekarbela, Kota Mataram

4. Semua pihak yang tidak dapat disebutkan satu persatu.

\section{DAFTAR RUJUKAN}

\section{Buku}

[1] Cohen, Lou. "Quality Function Deployment, How to make QFD Work for You". Addison-Wesley Publishing Company : New York, 1995

[2]Ismayanti. Pengantar Pariwisata. Jakarta: Grasindo. 2011.

[3]Lyon, F., dan Atherton, A, View of Clustering : Lesson for Cluster Development Policies. Foundation for SME Development, 2000.

[4]Medlik S, MA., and Middleton, The Product Formulation In Tourism, Association Internationale d'Experts du Tourism (AIEST), 1973.

[5]Singarimbun, Masri dan Effendi Sofian, Metode Penelitian Survei. Pustaka LP3ES Indonesia, Jakarta, 2009.

[6]Uphoff, Norman, Local Institutional Development: An Analitycal Sourcebook with Cases, Kumarian Press, West Hartford, Connecticut, 1986.

\section{Jurnal}

[7] Silas, Johan, "Permukiman Kumuh Jakarta Tinjauan Kontradiktif - Komparatif”. Masyarakat Jurnal Sosiologi. 2,1-9, 1993.

[8] Sushanti, IR. Pengaruh Keberadaan Industri terhadap Perumahan dan Kawasan Permukiman di Kota Mataram. Jurnal Sosial Ekonomi Humaniora. Universitas Mataram, Vol.1 No.1, 2015.

[9] Sushanti, IR dan Fitri, IS. Implications of Pearl, Gold, Silver (PGS) Craft Industrial Cluster Towards Settlements Region in Karang Pule Village, Sekarbela Districts of Mataram City. Jurnal International Conference Planning in The Era of Uncertainty: Sustainable Nation, 2017

[10] Wearing, S.L. and Donald, Mc, "The Development of Community Based Tourism: Re-Thinking The Relationship between Tour Operators and Development Agents as intermediaries in rural and isolated area Communities." Journal of Sustainable Tourism, 2001

\section{Kebijakan}

[11]Keputusan Walikota Mataram Nomor 526/X/2009 tentang Penetapan Klaster Industri Kecil Unggulan Kota Mataram, 2009

[12]Peraturan Daerah No. 12 Tahun 2011 tentang Rencana Tata Ruang Wilayah (RTRW) Kota Mataram tahun 2011 - 2031, Mataram, 2011.

[13]Peraturan Menteri Pekerjaan Umum Nomor 06/PRT/M/2007 tentang Rencana Tata Bangunan dan Lingkungan, Jakarta, 2007.

[14]Undang - Undang No 10 Tahun 2009 tentang Kepariwisataan, 2009.

[15] Undang - Undang No 3 Tahun 2014 tentang Perindustrian, 2014.

\section{Prosiding}

[16] Sushanti, IR., Irawan, SW., Widayanti, BH., Pengembangan Klaster Industri Kerajinan Mutiara, Emas, Perak (MEP) Sebagai Kawasan Pariwisata Belanjadi Kelurahan Karang Pule, Kecamatan Sekarbela, Kota Mataram. Prosiding Seminar Nasional Pembangunan Inklusif Desa - Kota, Universitas Andalas, Padang, Sumatera Barat, 2016. 


\section{PROFIL PENULIS UTAMA}

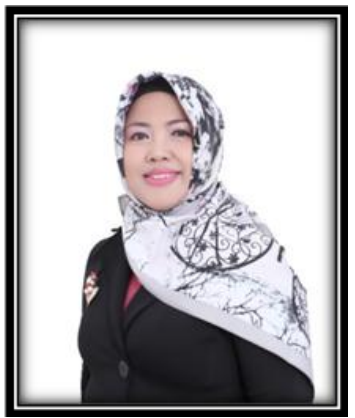

Biografi Lengkap Penulis Utama:

a. Nama: Ima Rahmawati Sushanti, S.T., M.M.T.

b. Pendidikan:

- S1 Arsitektur ITS Surabaya

- S2 Manajemen Industri, Magister Manajemen Teknologi ITS Surabaya

c. Publikasi Ilmiah:

- Sushanti, IR. Pengaruh Keberadaan Industri terhadap Perumahan dan Kawasan Permukiman di Kota Mataram. Jurnal Sosial Ekonomi Humaniora. Universitas Mataram, Vol.1 No.1, 2015.

- Sushanti, IR., Irawan, SW., Widayanti, BH., Pengembangan Klaster Industri Kerajinan Mutiara, Emas, Perak (MEP) Sebagai Kawasan Pariwisata Belanjadi Kelurahan Karang Pule, Kecamatan Sekarbela, Kota Mataram. Prosiding Seminar Nasional Pembangunan Inklusif Desa - Kota, Universitas Andalas, Padang, Sumatera Barat, 2016.

- Sushanti, IR dan Fitri, IS. Implications of Pearl, Gold, Silver (PGS) Craft Industrial Cluster Towards Settlements Region in Karang Pule Village, Sekarbela Districts of Mataram City. IOP Conference Series : Earth and Environmental Science. International Conference, Urban and Regional Planning Department Of Brawijaya University, Malang - East Java 2017

- Sushanti, IR dan Ariani, S, Rumah Produktif Sebagai Upaya Pemanfaatan Ruang Hunian dan Usaha Klaster Industri Kerajinan Mutiara, Emas, Perak (MEP) di Kelurahan Karang Pule Kecamatan Sekarbela Kota Mataram. Prosiding Seminar Nasional Space 3 ; Membingkai Multikultur Dalam Kearifan Lokal Melalui Perencanaan Wilayah dan Kota, UNHI, Denpasar, 2017.

- Top Down Approach For Treatment Efforts Social Inequality and Optimization of Industrial Cluster Institutional Settlement MEP and Surrounding Region in Karang Pule, District Sekarbela Mataram City, Orasi Ilmiah Demografi Forum Workshop and International Conference. Demographic Dividend and Youth: Opportunities, Challenges, and Policy Agendas (DDYOcapa), University of Gajah Mada, Yogyakarta, 2017 